with sulphur dioxide and the solution boiled only a few minutes, other conditions being exactly the same as in the preceding series of experiments.

$\begin{array}{ccc}\begin{array}{c}\text { Te required. } \\ \text { Gram. }\end{array} & \begin{array}{c}\text { Te obtained. } \\ \text { Gram. }\end{array} & \begin{array}{c}\text { Error. } \\ \text { Gram }\end{array} \\ 0.1508 & 0.1374 & -0.0134 \\ 0.1701 & 0.1443 & -0.0258 \\ 0.1608 & 0.1535 & -0.0073 \\ 0.1521 & 0.1140 & -0.0381 \\ 0.1903 & 0.1781 & -0.0122\end{array}$

The following two experiments were made with a large excess of sulphur dioxide water along with a 6 per cent. solution of hydrazine and the solution heated six hours.

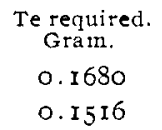

$$
\begin{gathered}
\text { re obtained. } \\
\text { Gram. } \\
\text { O. } 1545 \\
\text { O.14 I } 6
\end{gathered}
$$

$$
\begin{gathered}
\text { Frror. } \\
\text { Gram. } \\
-0.0135 \\
-0.0100
\end{gathered}
$$

The method which has been used in this laboratory for a number of years and which has proven the most satisfactory for the gravimetric determination of tellurinm is as follows: The tellurium either as derivative of the dioxide or as a tellurate, should be present in a solution which has an acidity of approximately ten per cent. of hydrochloric acid and it is preferable to have the solution sufficiently concentrated, otherwise the fine state of division of the precipitate will render it unsatisfactory for washing. The solution is heated to boiling and $\mathrm{I}_{5} \mathrm{cc}$. of a saturated solution of sulphur dioxide added, then io cc. of a 15 per cent. solution of hydrazine hydrochloride, and again $25 \mathrm{cc}$. of a saturated solution of sulphur dioxide. The boiling is continued until the precipitate settles in such a way that it can be easily washed. 'This boiling should not take more than five minutes. The precipitated tellurium after being allowed to settle is washed with hot water on a Gooch filter until all of the chlorine is removed, after which the water is displaced by alcohol and the crucible and contents dried at $105^{\circ}$.

UNIVERSITY OF WISCONSIN,

MaDison, WIs.

\title{
LOSS OF PHOSPHORIC ACID IN ASHING OF CEREALS.
}

\author{
BY SHERMAN IEAVITT AND J. A. L,ECLERC
}

Received December 26, 1907 .

Recent work in this laboratory on the determination of phosphoric acid in the ash of wheat has brought to the attention of the writers the fact that whereas the temperature below fusion, at which ashing of grain is carried on, makes very little difference in the percentage of ash, there is a loss in the corresponding values of phosphorus, varying with the temperature. 
The fact that there is danger of losing phosphorus where grains are allowed to become fused during ashing, has been known for some years, and the methods of the Association of Official Agricultural Chemists for the determination of phosphoric acid in ash were originated with this idea in view. In grains rich in phosphorus, such as cottonseed-meal. the methods of the A. O. A. C. prescribe charring and extracting the charred mass with acetic acid or water. Many analysts, however, do not consider it necessary to make a previous extraction on a grain comparatively low in phosphorus, such as wheat. Our results show that there is a loss of phosphorus below the fusing point of the ash, and, as stated above, this loss varies with the temperature.

The greater part of the phosphorus in wheat is in a water-soluble form known as phytin, a substance of relatively high molecular weight compared to the phosphorus molecule. A comparatively large percentage of the phosphorus may be lost in ashing without appreciably changing the amount of ash. Two grams of a sample of ground wheat were weighed into a flat platinum dish and ashed in a muffle at a temperature of low redness for five hours until the ash was gray or white. The ash was then weighed and dissolved in a few cubic centimeters of concentrated nitric acid and filtered and the determination of phosphoric acid made by the volumetric method of the Association of Official Agricultural Chemists.

It was found rather difficult to produce a perfectly white ash at the ten1perature used in the muffle, so a higher temperature was tried and the corresponding phosphoric acids determined. The substance used in every case was wheat ground so as to pass through a one millimeter sieve. Two series of ashings were carried out, one at low redness, in which the samples were allowed to heat up from the cold muffe, and the other set ashed at a distinct redness.
TABle I.-Average Results of Seven Samples Duplicated. Averages. low redness.

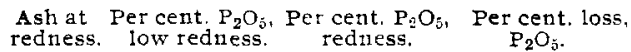 Seven samples... 2.02 1.99 0.74 0.40 46.0

The results from which Table I was obtained were all determined in duplicate and averaged, and the final table made from these averages. In every case the difference in the ash between ashing at redness and at low redness was less than o.I per cent., whereas the loss of phosphoric acid varied between 39 and 53 per cent.

As is well known, the addition of calcium acetate prevents the volatilization of phosphoric acid. Two samples in which the percentage of phosphoric acid had been previously determined by ashing with an excess of calcium acetate were then ashed in the ordinary way in the muffe at a comparatively low temperature, one duplicate of each determination being placed in the back part of the muffle and the corresponding ones in the front of the muffle. 
TABLE II.

\begin{tabular}{|c|c|c|c|c|c|}
\hline $\begin{array}{l}\text { Number } \\
\text { of sample. }\end{array}$ & $\begin{array}{c}\text { Per cent. } \\
\mathrm{P}_{2} \mathrm{O}_{5} \text { by cal- } \\
\text { cium acetate. }\end{array}$ & $\begin{array}{l}\text { Percent. } \\
\mathrm{P}_{2} \mathrm{O}_{5} \text {. Back } \\
\text { of muffle. }\end{array}$ & $\begin{array}{l}\text { Per cent } \\
\mathrm{P}_{2} \mathrm{O}_{5} \text {. Front } \\
\text { of muffle. }\end{array}$ & $\begin{array}{l}\text { Per cent. } \\
\mathrm{P}_{2} \mathrm{O}_{5} \text { lost. Back } \\
\text { of muffle. }\end{array}$ & $\begin{array}{l}\text { Per cent. } \\
\mathrm{P}_{2} \mathrm{O}_{5} \text { lost. Front } \\
\text { of muffe. }\end{array}$ \\
\hline 2 I 5 & 1.03 & $\circ 85$ & 0.97 & I $7 \cdot 5$ & 5.8 \\
\hline 2155 & 1.05 & 0.63 & 0.90 & 40.0 & I 4.3 \\
\hline
\end{tabular}

We see from Table II that the loss of phosphoric acid is greatest in the back of the muffle where it is hottest and least in the comparatively cool part of the muffle. The loss in either case, however, is an appreciable one and shows the necessity for ashing at a comparatively low temperature.

In order to make a more thorough study of this loss of phosphorus a number of samples were ashed in the regular way at redness; a duplicate set was also ashed by treating with $5 \mathrm{cc}$. of a solution of calcium acetate of such a strength to furnish more than enough calcium to fix all of the phosphoric acid and render it non-volatile. (A solution yielding about 0.03 grams $\mathrm{CaO}$ in $5 \mathrm{cc}$. of the solution is suitable for 2 grams of grains.) The samples treated with calcium acetate solution were heated on a steam bath to dryness and burnt over the free flame and finally heated for fifteen minutes over the blast lamp and weighed for ash, allowing for the correction of calcium oxide in 5 cc. of the acetate solution. Phosphoric acid was determined in the ordinary way.

Twenty-three samples of wheat gave the following results:

TABLE III.

$\begin{array}{cccccc}\begin{array}{c}\text { Per cent. } \\ \text { ash at } \\ \text { reduess. }\end{array} & \begin{array}{c}\text { Per cent. } \\ \text { ash, ace- } \\ \text { tate method. }\end{array} & \begin{array}{c}\text { Per cent. } \\ \text { loss, ash. }\end{array} & \begin{array}{c}\text { Per cent. } \\ \mathrm{P}_{2} \mathrm{O}_{5} \text { in ash } \\ \text { at redness. }\end{array} & \begin{array}{c}\text { Per cent. } \\ \mathrm{P}_{2} \mathrm{O}_{5,} \text { ace- } \\ \text { tate method. }\end{array} & \begin{array}{c}\text { Per cent. } \\ \mathrm{P}_{2} \mathrm{O}_{5} \text { lost. }\end{array} \\ 2.09 & 2.07 & \mathbf{1 . 0} & 0.64 & 0.99 & 35.0\end{array}$

Eighteen of the above samples gave a difference of less than o.Io per cent. between the ash at redness and the ash by the acetate method. The phosphoric acid varied between ro and 50 per cent. loss. Table III shows us that there is no appreciable loss of ash but a loss of 35 per cent. of the total phosphorus determined as phosphoric acid.

Samples when ashed at a very low temperature (the dishes radiate a faint glow) for five hours in a muffe, gave practically no loss of $\mathrm{P}_{2} \mathrm{O}_{5}$. Nineteen samples gave the following results:

TABLE IV.

\begin{tabular}{|c|c|c|c|c|c|}
\hline $\begin{array}{l}\text { Ash, ordi. } \\
\text { nary method, } \\
\text { low redness. }\end{array}$ & $\begin{array}{l}\text { Per cent. } \\
\text { ash, calcium } \\
\text { acetate method. }\end{array}$ & $\begin{array}{l}\text { Per cent. } \\
\text { loss, ash. }\end{array}$ & $\begin{array}{l}\text { Per cent. } \\
\mathrm{P}_{2} \mathrm{O}_{5} \text {, ordi- } \\
\text { mary method }\end{array}$ & $\begin{array}{l}\text { Per cent. } \\
\mathrm{P}_{2} \mathrm{O}_{5} \text {, calcium } \\
\text { acetate method. }\end{array}$ & $\begin{array}{l}\text { Per cent. } \\
\text { loss, } \mathrm{P}_{2} \mathrm{O}_{5} \text {. }\end{array}$ \\
\hline 1.95 & 1.93 & I.O & 0.91 & 0.93 & 2.0 \\
\hline
\end{tabular}

Thirteen of the above samples varied less than o.10 per cent. between ash results by the two methods and all of the phosphoric acid results checked within o. Io per cent. Determination of ash and phosphoric acid are almost identical. 
All of our results show that the temperature of ashing below fusion is not so important a factor where only the pereentage of asl is desired, but when determining the phosphorus as phosphoric acid in ash the greatest caution must be observed to kecp the tomperature below the rolatilization point of the combined phosphorus.

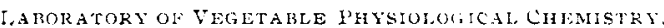
BLREAL Ol CHVMISTRY.

I: S. DHPARTMENT OF ACRICLITTRT
}

\title{
THE COLORED SALTS OF SCHIFF'S BASES.
}

\section{A Contribution to Our Knowledge of Color as Related to Chemical Constitution.}

\author{
BY li. J. MOORE ANI R. D. GALE. \\ Received January 6 , rgok.
}

\section{The Hydrochlorides of Bases Formed by Condensing p-Amino Di- methylaniline with Aromatic Aldehydes.}

The starting point of the present investigation was a chance observation made upon the compound produced by condensing p-aninodimethy aniline with piperonal. This product is of a light orange color and has the formula

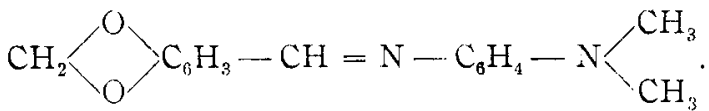

When this substance, either in the dry state or in ethereal or benzene solution, is treated with dry hydrochloric acid gas, one molecule of the latter is first added to form a salt of a deep blood-red color. This salt can further add another molecule of the acid to form a dibydrochloride. The color of the latter salt, in sinarp contrast to that of the former, is a bright lemon-yellow.

We found this phenomenon so striking that we determined to prepare a number of compounds of analogons constitution and study the color of their salts. The first substances selected were those most strictly analogous to the one already mentioned. namely, the condensation prorlucts of $p$-aminodimethylaniline with aronatic aldehydes. These bases furnish the subject matter of the present paper. They all show a be havior toward hydrochloric acid, and (so far as has been tested) also toward other acids, entirely analogous to that described in the case of the piperonal compound. A minor exception has to be noted in the case of anisaldehyde. When its condensation product with p-anino dimethylaniline is treated with hydrochloric acid, the same color changes are obserred as in the other cases, but analysis of the products show that a maximum of nearly thee nolecules of the acid is here alsorber. This behavior will be discussed more fully in the experimental part. 